\title{
Pole-weapons in the Sagas of Icelanders: a comparison of literary and archaeological sources
}

\author{
Jan H. Orkisz, \\ Chapitre des Armes (Paris), \\ orkisz.jan@gmail.com
}

\begin{abstract}
The Icelandic sagas are a major source of information on the Vikings and their fighting prowess. In these stories, several mysterious pole-weapons appear, which are often called "halberds", for lack of a better word. In order to better identify what these weapons could have been, and to provide a better understanding of how the sagas relate to the Viking-age events they describe, we confront textual and archaeological evidence for several of these weapons (the böggspjót, the atgeirr, the kesja, the krókspjot, the bryntroll and the fleinn), keeping in mind the contextualisation of their appearances in sagas. The description of the use of each weapon allows to pick several candidates likely to correspond to the studied word. Without a perfect knowledge of what context the authors of the sagas wanted to describe, it appears to be impossible to give a final answer. However, we show that some specific types of spears are good candidates for some of the studied weapons.
\end{abstract}

Keywords - Early Middle Ages; Viking Age; pole-weapons; archaeology.

\section{INTRODUCTION}

\section{I.1. Context}

Vikings, their weapons and fighting prowess have fascinated people and raised a great interest since the $19^{\text {th }}$ century, with the rise of romantic nationalism. Among the major sources that stimulate the imagination about these Scandinavian warriors are the Icelandic sagas, which tell the tales of many Viking-age heroes.

Among the weapons used by these Norsemen to achieve glory and bloodshed, some are very common, like the sword, axe or spear. But some weapons are much rarer, appearing only a few times in the sagas, and have names of unclear meaning in Old Icelandic (Old Norse). For lack of a better word, their names are often rendered as "halberd" or "bill", in literary translations of the sagas. For pole-weapons of an unknown nature, it can be a good option to put them under such umbrella terms, which in later medieval times referred to weapons with a huge variety of shapes.

However, is there any ground to compare e.g. a kesja or an atgeirr to what later became known as a halberd (Fig. 1)?

It seems that the path of thought followed by most translators is the following: if a poleweapon is not a spear, and is able to cut and thrust, it means that it has a complicated 
shape, which makes it akin to a halberd. Others are more conservative, and assume that the shape of that weapon cannot be as complex as a halberd, and settle for something simpler, like a bill (or glaive). At best, intertextual studies relate these weapons to one another $^{1}$ or to other European weapons ${ }^{2}$. However, in these translations and comparisons, there is no sign of research into the archaeological evidence and martial arts of the time, and there is a general agreement on the fact that we don't really know what Viking-age "halberds" were, maybe because they were so rare that not a single specimen survived to our day.
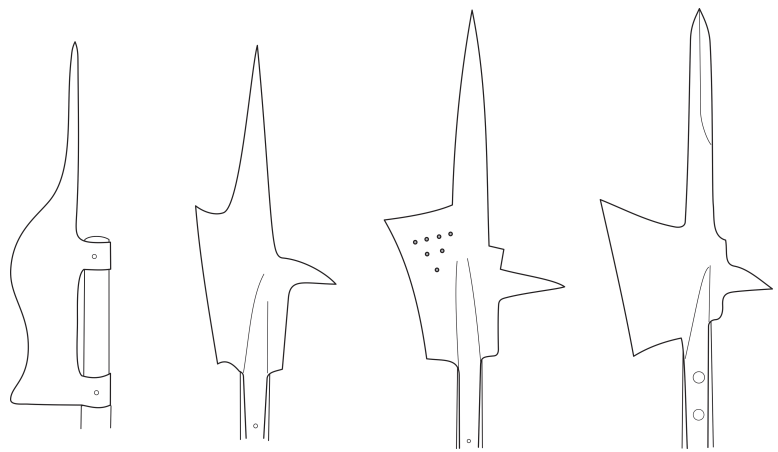

Figure 1: Examples of European halberds (to scale) from about 1400 to 1500, based on examples of the Metropolitan Museum (New York).

Our goal is to do this archaeological and martial research, to try and provide viable archaeological candidates for these unknown weapons, and a better understanding of the way they might have been wielded.

\section{I.2. Methodology}

The goal of our study is to compare the description that is made of these pole-weapons in the sagas with archaeological and pictorial evidences, in order to identify what kind of weapon was designated by a given word.

To do this comparison, there is a major caveat that has to be taken into account, namely the literary context of the sagas. The sagas describe events that happened in the Viking Age, between the $9^{\text {th }}$ and the $11^{\text {th }}$ century. However, the texts were not written down until the $13^{\text {th }}$ century, some of the latest sagas being even dated to the early $14^{\text {th }}$ century. Even if many sagas refer to historical characters and events, they are by no means history books, but rather literary works. Therefore, one does not expect them to give a realistic account of what happened - it is likely that instead, the authors distorted the facts to enhance the legendary or heroic nature of their protagonists. For example, elements of magic can be present in sagas which mention undoubtedly historical characters. It is also unlikely that

\footnotetext{
${ }^{1}$ Cleasby and Vigfusson, An Icelandic-English Dictionary, e.g. entry "atgeirr".

${ }^{2}$ Falk, Altnordische Waffenkunden, chapters 3 and 5.
} 
the authors referred properly to 300-year old weapons: as it can be seen in paintings and manuscripts throughout all of the Middle-Ages (and, to some extent, in later periods as well), ancient characters are often wearing clothes, equipment and weapons that are either contemporary to the artist, or at most a few decades outdated which was deemed enough to give the impression of a time long past ${ }^{3}$. Besides, the authors of the sagas are not expected to be experts on military topics. They might therefore be misusing the names of the weapons, either involuntarily, by simple ignorance, or voluntarily, to embellish their text at the cost of technical accuracy.

When studying the descriptions of the weapons and their uses in the sagas, we must be careful with three things:

- the setting of the saga might be quite historically accurate for the Viking Age, or it can be contemporary to the author, and correspond to anywhere between the $10^{\text {th }}$ and the $13^{\text {th }}$ century.

- the related feats of arms can describe a realistic way of using the weapon, which the author can have heard (in the case of Viking-age weapons) or seen by himself (for 13th-century weapons), or it can be a literary overstatement that should be taken with a pinch of salt.

- the names of the weapons can sometimes by voluntarily or involuntarily misused by the authors. Since this last point is virtually impossible to verify, we will have to carefully check whether the various accounts on a given weapon are consistent with one another.

To carry out our study, we use an extensive list of references to weapons, armour and combat in the Sagas of Icelanders ${ }^{4}$ to find the occurrences of the names of the studied weapons: the böggspjot, the atgeirr, the kesja, the krókspjott, the bryntroll and the fleinn. This database is constructed thanks to the full text of the Icelandic Sagas ${ }^{5}$, and their full translation in English by Viðar Hreinsson and Katrina C. Attwood ${ }^{6}$. The search in the database is carried out according to the Icelandic text, since the English translation can be somewhat inconsistent, and the weapons that we study can be found under the names of "halberd", "thrusting spear", "spear", "bill", "double-bitted axe" or "pike". The identified sections of the sagas are cross-checked with their (Old) Icelandic and English versions, when available, in an online database ${ }^{7}$.

\footnotetext{
3 See, e.g., the depiction of Biblical times in the Maciejowski Bible, ca. 1245 (New York, Morgan Library, Ms. M. 638), or the depiction of Norse heroes in Renaissance manuscripts of the Icelandic Sagas.

${ }^{4}$ Short, Arms and Armor in Sagas.

5 Anonymous, Íslendinga sögur, ed. Halldórsson et al.

6 Anonymous, The Complete Sagas of Icelanders, ed. Hreinsson, transl. Attwood.

7 Available at <http://sagadb.org/index_az> (accessed 01 December 2016).
} 
For each weapon, we start by narrowing down our search for archaeological candidates by explaining the meaning of the name and its etymology. After that, we make an extensive list of the appearances of its name in the sagas of Icelanders. Then, we classify these occurrences based on the way the weapon is described or used, and try to use these statistics to compare the weapon with the archaeological artefacts or with the knowledge about later pole-weapons.

We then list the possible archaeological candidates for the weapon from the Viking Age to the $13^{\text {th }}$ century, and, comparing these candidates to the descriptions in the sagas and the literary context, we try to find the most likely type of object corresponding to the weapon's name.

\section{HÖGGSPJÓT}

\section{II.1. Literary occurrences}

\section{II.1.1. Etymology}

The etymology and meaning of the word böggspjot are quite clear. The two roots here are the noun spjót, which is the most common word to denote a spear ${ }^{2}$, and the verb höggva.

The verb böggva means "to strike, to smite"10. With a weapon or tool, it takes the meaning "to cut", hence the term höggvapn (cutting weapon, as opposed to a thrusting weapon lagvapn $)^{11}$. It is worth noting that it is the verb used when cutting down a tree (böggva upp tre $)^{12}$, or when using an axe. The "cut" implied by this verb is therefore about chopping, not slicing.

We have the impression of a weapon being closely related to a spear, but still being able to chop like an axe. Given this etymology, we will use the translation "hewing spear" for this weapon.

\section{II.1.2. Appearance in sagas}

The böggspjot appears sporadically in various sagas. Unfortunately, this corpus is quite small, and not very specific about the shape or the use of the weapon:

\footnotetext{
8 We use the standardized orthography for Old Norse, with $\ddot{o}$ designating the long open [0] sound, often also written $Q$.

${ }^{9}$ Cleasby and Vigfusson, An Icelandic-English Dictionary.

10 Zoëga, A Concise Dictionary Of Old Icelandic.

11 Ibid.

12 Ibid.
} 
- In Egils Saga (chapter 58), Egil is wielding a böggspjót in one hand, while carrying a shield in the other hand. The same weapon gets referred to as a spjót and a kesja ${ }^{13}$.

- In Gísla Saga (chapter 2), Gisli uses a böggspjót to cut through a shield and its bearer ${ }^{14}$.

- In Kormáks Saga (chapter 16), Bersi wields a böggspjót in one hand, and a parrying stick in the other hand ${ }^{15}$.

- In Króka-Refs Saga (chapter 3), Refs takes a "big” höggspjót, and later uses it as a throwing spear ${ }^{16}$.

- In Ljósvetninga Saga (chapter 12), Bjarni mentions his höggspjót. The same weapon is also referred to as a skaftamunur in Icelandic, translated as a "pike"17. The Old Norse form might have been *skaptamunr, meaning a "shafted thing", i.e. a pole-weapon.

- In the same saga (chapter 19), Thorkel takes a böggspjót and wields it in two hands.

- In Víga-Glúms Saga (chapter 22), Glum is said to have a höggspjót, probably used in one hand.

- In Vopnfirðinga Saga (chapter 2), Svart makes a two-handed thrust with a "big" höggspjót ${ }^{18}$.

The weapon is several times referred to as being big. It might be an indicator that a böggspjot is larger than a common spear, but it might just as well signify that the weapon described in the text is big even for a böggspjót.

We can see that this weapon appears to be used in one hand (with a shield or a parrying stick) as well as in two hands. It is similar to the way a simple spear can be wielded, and implies a reasonable weight.

The weapon is used to thrust, but also seems to possess an impressive cutting power, being able to chop through shield and man. Here again, we have the confirmation of a chopping motion, since slicing would have been rather ineffective against a wooden shield. It is worth noticing that it is the narrow "tail" of the shield which is said to be cut through ${ }^{19}$, clearly implying a kite-shaped shield and a $13^{\text {th }}$ century context for Gísla Saga (Fig. 2b, Fig. 7a).

\footnotetext{
13 Appendix 10, 11 and 12.

14 Appendix 15.

15 Appendix 17.

16 Appendix 18.

17 Appendix 19.

18 Appendix 20.

19 Appendix 15.
} 

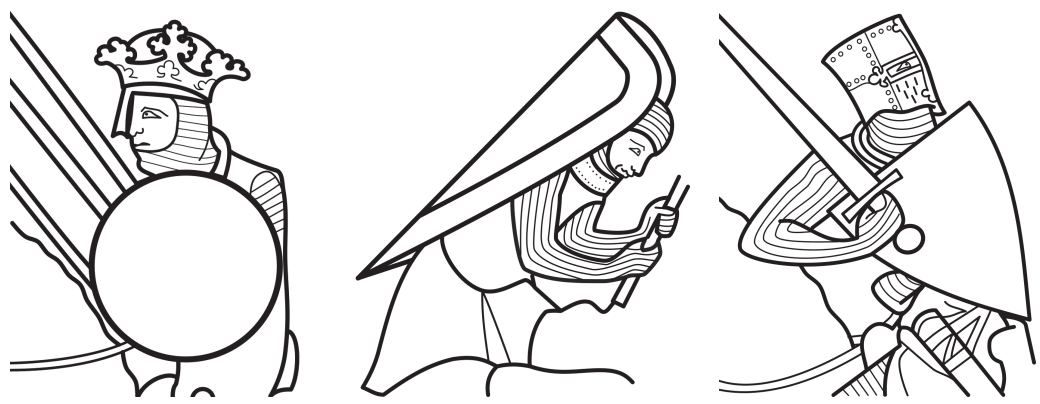

Figure 2: Example of 13th century strapped shields: round targe (a), and transition from a large kite shield (b) (here worn on the back) to a smaller heater shield (c).

Based on the Maciejowski Bible, ca. 1245 (New York, Morgan Library, Ms. M. 638, f $9 v, 10 v$ and $10 r)$.

\section{II.2. Archaeological candidates}

Given the name of the weapon, we focus our search for archaeological candidates on spears and spear-like pole-arms, and do not look at any kinds of axes.

\section{II.2.1. Spears}

Let us first focus on spears, i.e. thrust-centric pole-weapon with a sharp, symmetrical blade. In almost any era since the Bronze Age, it is possible to find spears that are able to cut: one just needs to make a spearhead large and broad enough.

If we look at the Viking Age, we can find numerous examples of such spears, which are usually large specimens of Petersen types $\mathrm{B}$ and $\mathrm{C}^{20}$. Such large winged spears became popular during the Migration Era among the Germanic people, and can be found in Scandinavia as well as in continental Europe (Fig. 3 and 4).

These spearheads have blades broader than $5 \mathrm{~cm}$, which is the typical breadth of a Vikingage sword. The curved shape of their blades makes them good slicing weapons, allowing them to turn a near-missed thrust into a deep cut. Their weight can reach from over 500 $\mathrm{g}$ (Fig. 3a) to almost $2 \mathrm{~kg}$ (Fig. 4a). Combined with the leverage provided by a long shaft, this also gives to such spears the ability to chop powerfully.

Such spears can be found until the very end of the Viking Age; other types of broad and heavy spears retain these slicing and chopping capacities in later medieval times (Fig. 6b and $6 c)$.

20 Petersen, De Norske Vikingesverd, pp. 23-24. 

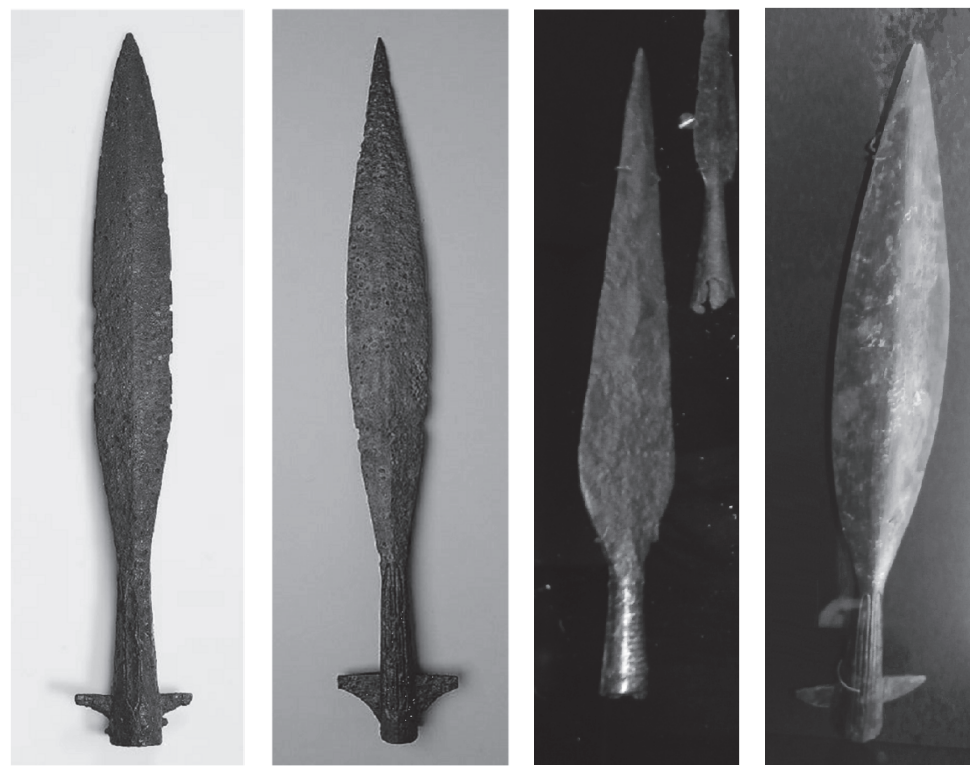

Figure 3: Large Viking spearheads with a cutting capacity. a: $41 \mathrm{~cm}$ long spearhead with 6.8 cm wide blade, (Stockholm, Statens Historiska Museet, catalogue nr. SHM 7571:256 (obj. 450765)), photograph: (C) Gabriel Hildebrand, b: $53 \mathrm{~cm}$ long spearhead with $6.7 \mathrm{~cm}$ wide blade, (Stockholm, Statens Historiska Museet, catalogue nr. SHM 34000:Bj 850 (obj. 372011)), photograph: (C) Christer Ahlin. Reproduced with permission of the institution. c: spearbead, $\sim 70 \mathrm{~cm}$ long, $\sim 9 \mathrm{~cm}$ wide (Copenhagen, National Museum), own picture and estimations. $\boldsymbol{d}$ : spearbead, $\sim 60 \mathrm{~cm}$ long, $\sim 7 \mathrm{~cm}$ wide blade (Busdorf, Haithabu Museum), own picture and estimations.
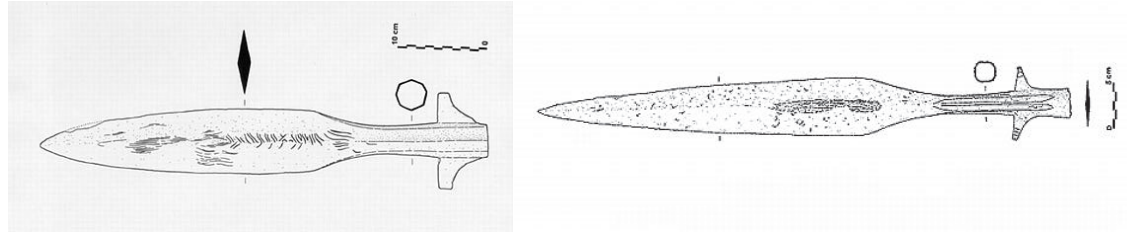

Figure 4: Other Viking-age spearbeads. a: Frankish $50.2 \mathrm{~cm}$ long spearhead with $7.2 \mathrm{~cm}$ wide blade, 9th century, (Chalon-sur-Saône, Musée Denon, catalog nr. 93.34.5), and b: Frankish

$58.7 \mathrm{~cm}$ long spearhead with $6.5 \mathrm{~cm}$ wide blade, 11th century, (Chalon-sur-Saône, Musée

Denon, catalog nr. 67.4.2). Drawings by C. Michel. Reproduced with permission of the institution.

\section{II.2.2. Glaives}

Among other types of pole-weapons, the one with the closest shape and use to a spear is the glaive. If we describe a spear as a dagger on a pole, then a glaive would be a knife on a pole: single edged, and designed as much to cut as to thrust. 
Examples of glaives start to be seen in the $13^{\text {th }}$ century - and would have therefore been contemporary to the authors of the sagas.
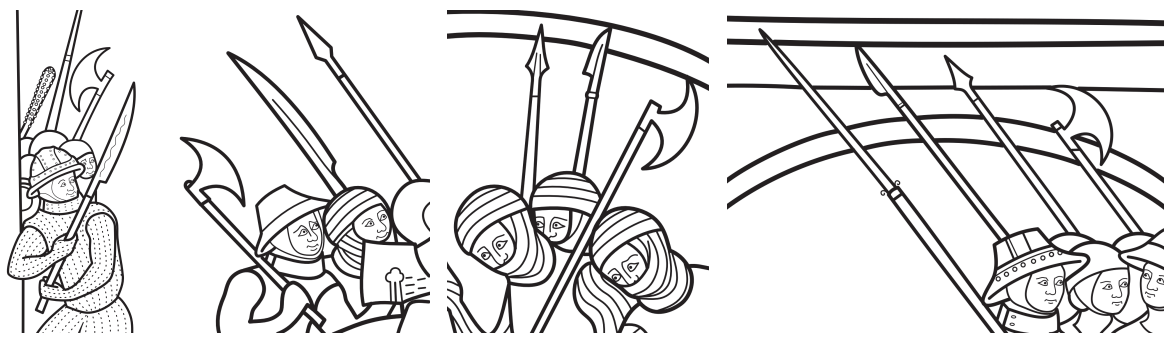

Figure 5: Illustrations of 13 th century pole-weapons. Panels $\boldsymbol{a}$ and $\boldsymbol{b}$ show a large-bladed glaive or falchion. The weapon is always used two-handed, but can be long-or short-shafted, used either on foot or on horseback. Panels $\boldsymbol{c}$ and $\boldsymbol{d}$ show a smaller glaive, which almost looks like half of a normal spearhead, except that is has a clearly curved cutting edge. Other shown weapons are spears, axes, maces, and what seems to be a mail-piercing pike similar to a later ablspiess ${ }^{21}$ (a and $\boldsymbol{d}$ ). Based on the Maciejowski Bible, ca. 1245 (New York, Morgan Library, Ms. M. 638, fo 10r, 42r, $15 r$ and $27 v$ ).

Early examples of glaives appear in several folios of the anonymous Maciejowski Bible from ca. 1245 (Fig. 5). The first kind of glaive (Fig. 5a, 5b) appears on folios 10r, 10v and 42r. It is something half-way between a huge falchion and a glaive. The blade is extremely large, and the shaft is sometimes very short. The second kind appears on folios 15r, 16v, $17 \mathrm{r}, 27 \mathrm{v}, 43 \mathrm{r}$ and $43 \mathrm{v}$, and is the exact opposite, with long and thin shafts and small blades. Surprisingly, the blade is always backwards when the weapon is used on horseback, indicating that the horsemen did not use it for cutting.

It is reasonable to think that intermediate-sized glaives had started emerging by the same time. Fig. 6 a depicts a later ( $15^{\text {th }}$ century) glaive, which would have such an intermediate size: a blade about $60 \mathrm{~cm}$ long on a $\sim 2 \mathrm{~m}$ shaft.

\footnotetext{
21 Oakeshott, European Weapons and Armour, p. 52
} 


\section{II.3. Interpretation}

An important hint to understand the nature of the studied weapons might come from later sources on combat with pole-weapons.
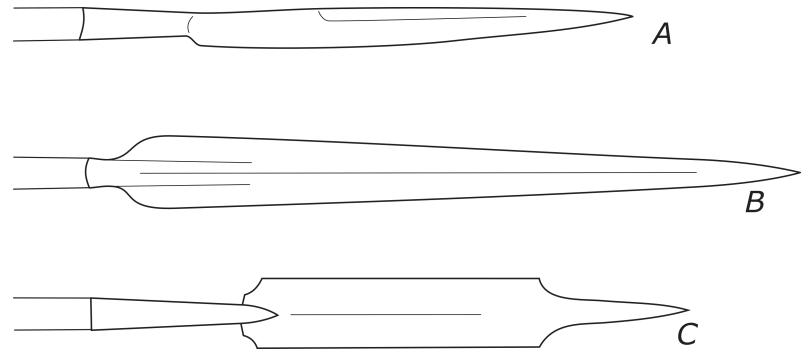

Figure 6: Examples of late medieval cut-and-thrust pole-weapons that are most closely related to the spear, based on museum examples (to scale). a: a late 15th century glaive, similar to the older weapons seen in Fig. 5. b: a large 15th century spear. c: a broad-bladed ox-tongue spear from the late $15^{\text {th }}$ century. Weapons such as $\boldsymbol{b}$ and $\boldsymbol{c}$ evolved into partisans during the

Renaissance.

Let us focus on the fact that the böggspjot can be used either two-handed, or one-handed with a parrying device (stick or shield) in the other hand. In later medieval and Renaissance fencing treatises, fighting with a pole-weapon and a shield is rarely described, but when it is the case, the weapon is always a spear, or a spear-like (symmetrical) weapon ${ }^{22}$. One could argue that the fencing treatises being often more duel than battleoriented, it is not surprising to see few mentions of typically battlefield weapons such as the bill, the glaive... and that the use of the shield is less needed in a duelling context. This would be true, but the fact that only spears (light or heavy) are used in conjunction with a shield is overwhelmingly supported by pictorial evidences. The one-handed use of a pole-weapon such as a glaive or a halberd is extremely rarely, if ever, represented in artwork.

The reason for this is mechanically quite simple: to deliver an effective cut, one needs to apply enough torque on the handle of the weapon - which would not be possible with the strength of a single wrist and the large leverage of a pole-weapon. Therefore, if used one-handed, a pole-weapon can only be used effectively to thrust or to slice (draw-cut) ${ }^{23}$. The use of the höggspjót can be very well compared with the use of the partisan ${ }^{24}$ : we have in both cases a heavy spear-like weapon with a cutting capacity, which can be used two-

\footnotetext{
22 For example in Achille Marozzo, Opera Nova, (book 4, chap. 179), in Die Blume des Kampfes (Vienna, Österreichische Nationalbibliothek, Cod. 10799) or in Gladiatoria (Cracow, Biblioteka Jagiellońska, MS Germ. Quart. 16).

23 Achille Marozzo, Opera Nova, book 4, chap. 179, introduction.

24 Ibid., chap. 179 and 180.
} 
handed or with a shield. The length, width and weight of partisans are also similar to the spears in Fig. 3 and 4.

It seems therefore reasonable to conclude that höggspjót is a word used to describe a large spear with a cutting capacity - as the name says it, a "hewing spear". Like any spear, it would be used mostly for thrusting, and could sometimes be used for slicing, be it oneor two-handed. Its specificity (and hence its name) compared to smaller spearheads would be its ability to chop (böggva) effectively when used two-handed.

\section{ATGEIRR}

\section{III.1. Literary occurrences}

\section{III.1.1. Etymology}

The word atgeirr is older that the Viking Age, and cognates can be found in Old English and other Germanic dialects (atiger, setgare, aizger), deriving from the Germanic root gar (in Old Norse geirr), meaning a spear ${ }^{25}$. In earlier Germanic languages, gar and setgar rather designates a heavy spear (as opposed to a light javelin), while geirr is just a common name for any spear in Old Norse ${ }^{26}$. Therefore, we are encouraged to think of a weapon closely related to a spear - something long-shafted and thrust-oriented.

The main question is to know what special meaning the prefix at-is giving to this word.

A first interpretation is to see it as deriving from the Latin ad-, which would be used in this case as an intensive ${ }^{27}$. In this scope, atgeirr can be interpreted meaning a "very spear", an "excellent spear".

When comparing with other Old Norse words, we can also notice that the prefix at often gives a martial meaning to words.

It derives from the word at (f.): poet. collision, clash, fight ${ }^{28}$. We can find this martial meaning in many words such as atferð, atganga (and atgangr), athlaup, atlaga, atras, atreið, atróðr, atsókn, atvígi, which all mean "(go, ride, row to) attack", "(to) fight"29.

In this context, we can understand the word atgeirr as denoting a "battle spear" - as opposed to a light javelin or a hunting spear, it underlines the man-killing character of the weapon, which is depicted in Brennu-Njáls saga as almost having a blood-lust on its own.

${ }^{25}$ Keller, The Anglo-Saxon Weapon Names, p. 21.

26 Zoëga, A Concise Dictionary Of Old Icelandic.

${ }^{27}$ Keller, The Anglo-Saxon Weapon Names, p. 130.

${ }_{28}$ Cleasby and Vigfusson, An Icelandic-English Dictionary.

29 Ibid. 
Last but not least, the word atgeirr was kept in use in the Icelandic language and took the meaning of a regular European halberd (Fig. 1).

\section{III.1.2. Appearance in sagas}

The atgeirr appears in three different sagas: most prominently in Brennu-Njáls Saga, but also in the Laxdœla Saga and the Eyrbyggja Saga.

It is interesting to note that these three sagas are closely related. They all focus on events which historically happened around the same time (late 10th and early $11^{\text {th }}$ century), and feature several characters in common, among which the famous Snorri Goði. The three sagas were written in the mid to late $13^{\text {th }}$ century. Eyrbyggia Saga probably dates back to prior $1264^{30}$, Laxdœla Saga to about $1230-1260^{31}$, and Brennu-Njáls Saga was probably first written between 1270 and $1290^{32}$.

It is likely that the (unknown) author of Eyrbyggja Saga knew the text of Laxdœla Saga, and that the author of Brennu-Njáls Saga knew the two previous ones. It is therefore possible that the author of Brennu-Njáls Saga chose from the weapons mentioned in the two older sagas the name he saw most fitting for the fearsome weapon that became central to Gunnar Hámundarson's story.

We therefore assume that the authors of the three sagas had the same weapon in mind when using the word atgeirr.

\section{- Brennu-Njáls saga}

It is in this saga that the atgeirr achieved fame. The weapon's name is mentioned no less than 51 times, with about $69 \%$ of these appearances happening in the context of a fight or battle. The atgeirr of this saga is obviously a very special weapon. Save for its first appearance and a mention as "Gunnar's atgeirr", 49 times out of 51 is it mentioned in a definite form, as "the atgeirr" (atgeirinn) ${ }^{33}$. In contrast, even weapons as important as swords are often usually in an indefinite form (e.g. "Sigmund was girded with a sword"34) unless they have a name or a special context attached to them. This proves how unique the atgeirr is. It is also explicitly mentioned as being a magical weapon. In the first two occurrences where the weapon (then belonging to Hallgrim) is mentioned (chapter 30), it is explained how it has been enchanted - one of its powers being a loud ringing of the blade foretelling killings ${ }^{35}$. Later in the saga, this prophetic ringing is mentioned again

\footnotetext{
30 Mallet, Scott, et al. Northern Antiquities, p. 517.

31 Sveinsson (ed.), Laxdala Saga, p. xxv.

32 Gylfason (ed.), Njál's Saga, Introduction, p. XIII.

33 e.g. Appendix 4 and 5.

34 Appendix 3.

35 Appendix 2.
} 
(chapter 54), and in one occurrence, blood appears out of nowhere on the blade, as another sign of upcoming bloodshed (chapter 72).

\section{- In the other sagas}

The atgeirr appears also in one scene of each of the older sagas.

In Eyrbyggja Saga (chapter 26), it is mentioned three times in Svart's failed attempt to murder Snorri Goði. Each time, it is mentioned as a thrusting weapon.

In Laxdœla Saga (chapter 64), Hardbein thrusts an atgeirr through Thorstein's iron skullcap. This might show how powerful the weapon was, might be a literary exaggeration, or might be a realistic event of a spear made of good steel (a "very spear") cracking the iron of a poor quality skull-cap.

\section{III.1.3. Use as a weapon}

In none of the sagas is the atgeirr described. However, more information can be derived from the description of its use, in combat or otherwise.

Apart from using it in combat, Gunnar uses the atgeirr twice to vault himself onto his saddle (chapters 54 and 74). This is a good indicator of the geometry of the shaft.

To vault oneself high enough, there are two options. The first is to push downwards, ideally on a horizontal surface, if said surface is lower than shoulder-high - this would be possible by using e.g. the butt of a two-handed axe as the handle of a (tall) walking stick. The other option is to pull oneself up on a shaft higher than shoulder-high - this option matches more a shaft as long as a spear. Given our assumptions on the weapon, we keep the second option, and therefore conclude that Gunnar's atgeirr is as long-shafted as a (long) spear, meaning that the socket of the blade is at or above eye-level.

Table 1 summarizes all the fighting moves related to an atgeirr in the three sagas.

The first element that we will derive from these statistics are the guards used for this weapon.

Quite often, the fights are short or unexpected and are not described in details, so that it is difficult to know how the protagonists are equipped, and therefore if the atgeirr is used in one or two hands (16 cases out of 39). In the cases were we can guess how the weapon is held, we see that it is almost as often used one-handed as two-handed (12 vs. 11 cases).

It is worth mentioning that in the case of a one-handed use, Gunnar is described either wielding the atgeirr and a shield, or the atgeirr in one hand and a sword in the other one. It even happens that these two configurations are described in the same fight, somewhat inconsistently, since it is unclear how the Gunnar could sheathe / unsheathe his sword or discard / grab his shield at such a pace (chapter 54). 


\begin{tabular}{|c|c|c|c|c|}
\hline Move & One-handed & Two-handed & Unknown & Total \\
\hline Thrusting & 4 & 6 & 5 & 15 \\
\hline Cutting & 1 & 0 & 1 & 2 \\
\hline Lifting $^{36}$ & 1 & 2 & 1 & 4 \\
\hline Shooting $^{37}$ & 2 & 0 & 0 & 2 \\
\hline Parrying & 1 & 0 & 1 & 2 \\
\hline Twisting $^{38}$ & 0 & 1 & 0 & 1 \\
\hline Holding $^{39}$ & 0 & 2 & 6 & 8 \\
\hline Other ${ }^{40}$ & 3 & 0 & 2 & 5 \\
\hline Total & 12 & 11 & 16 & 39 \\
\hline
\end{tabular}

Table 1: Statistics of the use of an atgeirr in combat in Brennu-Njáls, Eyrbyggja and Laxdola Sagas. The number of hands holding the weapon is either explicitly mentioned in the saga, or derived from the context (used with a shield, another weapon, etc.)

When holding the weapon one-handed, and assuming that it is wielded more or less like a spear, another question arises about the guard, since three possible positions are depicted in artwork throughout history for the one-handed spear: the overarm, underarm and couched guards (Fig. 7). In two situations, we can guess what the guard of the protagonist is:

- when Gunnar shoots (thrusts or throws) the atgeirr through a enemy shield and its bearer in what seems to be a downward blow, we can guess the use of an overarm guard ${ }^{41}$,

- when Gunnar lifts an impaled Egil on the atgeirr with a single arm (chapter 63): the scene is quite obviously a literary overstatement, magnifying Gunnar's strength, but this feat can be marginally reasonable if a pivot point is provided by the armpit to use the shaft of the weapon as a lever. The blow might have been delivered from a couched or underarm guard, and the lifting is done in the couched guard.

The second, and probably most important element that we can study is the kind of blows delivered by this weapon. We therefore disregard here the actions of parrying or simply holding the weapon, which leaves us with 29 actions out of 39 .

\footnotetext{
${ }^{36}$ Lifting an impaled opponent.

37 Thrusting or throwing?

38 Twisting the blade in the wound.

${ }^{39}$ Holding, grabbing, raising, aiming...

40 Fighting, killing, running through.

41 Appendix 5.
} 

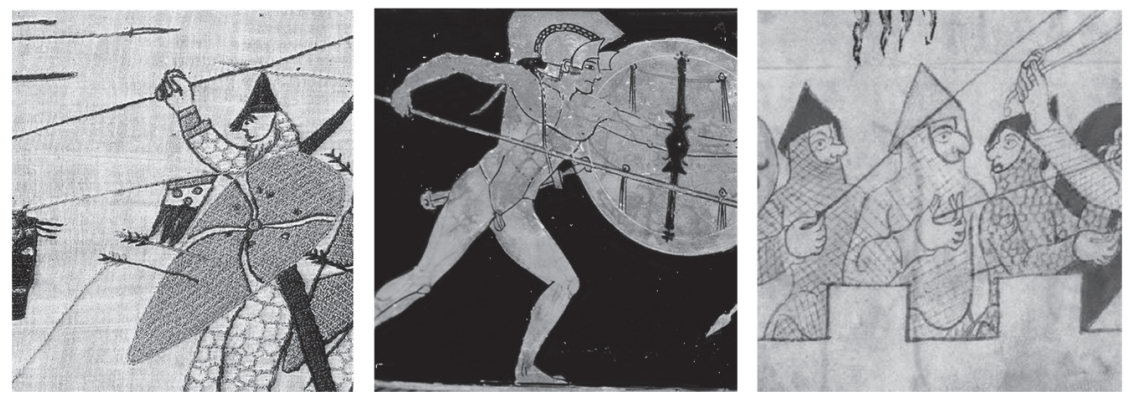

Figure 7: Spear and shield guards for infantry: overarm, underarm and couched spear. a: Bayeux Tapestry, 11th century, with special authorization of the city of Bayeux. b: Achilles fighting Hector, greek volute crater, (London, British Museum, catalog $n$ r. 1848,0801.1). (C) British Museum (CC BY NC SA 4.0).

c: Bible d'Étienne Harding, ca. 1109-1111 (Dijon, Bibliothèque municipale, Ms. 14,. $f^{\circ} 13 v$ ). Reproduced with permission of the institution.

We notice first that it is unclear from the text whether the verb "shooting" (skjojta) designates the action of throwing or thrusting the weapon. This verb applies to archery (skjóta af boga shooting a bow ${ }^{42}$ ), which could imply a meaning of throwing in the case of a pole-weapon, but it is also used for any quick forward motion (skjóta skildi fyrir sik to put a shield before oneself ${ }^{43}$ ), so a thrust is a possible option too. In the case of the atgeir, it seems that the weapon is immediately recovered and used again, which might prove a thrusting motion ${ }^{44}$. It is also consistent with the fact that a throw and a thrust from the overarm guard are basically the same motion.

Leaving aside the few occurrences where we are just told that the opponent is "killed", "run through" or receives his "death blow", etc. (5 cases out of 29), and the specific motions of twisting the blade (1 occurrence) and lifting the impaled opponent (4 occurrences), we can see that we are left with an overwhelming majority of thrusts. "Thrusting" and "shooting" occurs 17 times, whereas "cutting" only two times. Out of these two cuts, one is a cut through a spear shaft (chapter 79), and the other one is actually likely to be a cut made with a sword, since it occurs in a situation where Gunnar is fighting with the atgeirr in one hand and a sword in the other hand ${ }^{45}$. It is not obvious from the text whether the cut is made by the atgeirr or the sword, but the fight happens right after a scene where Gunnar describes a premonitory dream where he "cuts with his sword and thrusts with the atgeirr" (chapter 62).

\footnotetext{
42 Zoëga, A Concise Dictionary Of Old Icelandic.

${ }^{43}$ Ibid.

${ }^{44}$ e.g. Appendix 5.

45 Appendix 6.
} 
Therefore, if we limit ourselves to wounding blows that are described accurately, we end up with $100 \%$ of thrusts.

\section{III.2. Archaeological candidates}

Given its uses in battle and the strongly spear-related name, the atgeirr might be the same kind of weapon as the böggspjót (see section II.2).

The atgeirr being almost exclusively used for thrusting, we could have assumed that the weapon could be any type of spear. However, the instance where the atgeirr manages to cut (böggva) through a spear shaft indicates that it must have had a substantial blade.

The lifting of impaled opponents also gives a hint about the geometry of the blade, which prevents the body from sliding down the shaft: either the spear must be quite broad, or, even better, it must have wings on the socket (Fig. 3). Therefore, glaive blades do not make as good candidates as certain types of spears.

\section{III.3. Interpretation}

An important thing to note about Brennu-Njáls Saga is that it is very strongly set in a $13^{\text {th }}$ century context ${ }^{46}$. Apart from the details about customs and clothing, one of the most obvious indicators of this setting is the all-around presence of kite shields (Fig. 2b). The same goes for Laxdœla Saga, with the mention of kite shields as well as an iron skull-cap, which is a type of helmet that appeared only in the $12^{\text {th }}$ century ${ }^{47}$. Therefore, the author might have had a $13^{\text {th }}$ century weapon in mind when writing about the atgeirr.

However, one has to keep in mind that in Brennu-Njáls Saga, the atgeirr is clearly a unique weapon, at least due to its magical properties. It is therefore likely that the shape of the atgeirr would be unusual as well: the weapon could be either foreign, or ancient - which would be consistent with the old Germanic origin of the word.

We must therefore consider three options: the atgeirr of Brennu-Njáls Saga might be a normal, 13th-century Icelandic weapon, given a special name to emphasize its uniqueness, or a foreign, unusual weapon, or an ancient weapon, that would be anachronistic in a $13^{\text {th }}$ century context.

The fact that an atgeirr is casually mentioned in other sagas would tend to rule out the hypothesis of a foreign weapon - one would expect the authors to dwell more on the description of such a rare weapon, like the author of Brennu-Njáls Saga does when the atgeirr is first mentioned in the hands of Hallgrim.

The atgeirr is therefore most likely a type of spear that was at least to some extent known to $13^{\text {th }}$ century Icelanders. And, even though it contradicts the later meaning of the word atgeirr as a regular halberd, and even though the supposed uniqueness of the atgeirr in

\footnotetext{
46 Sigurðsson, The Medieval Icelandic Saga and Oral Tradition, pp. 301-303.

47 Nicolle, Knight of Outremer, 1187-1344, p. 51.
} 
Brennu-Njáls Saga makes it difficult to give an assertive conclusion, the best option for the atgeirr of the sagas, given its use, would be a large hewing spear, most probably with wings.

\section{KESJA}

\section{IV.1. Literary occurrences}

\section{IV.1.1. Etymology}

The word kesja has the least obvious etymology. It is supposed to derive from (or share a common origin with) the Celtic (Gaulish) word gasum, which means a javelin, or throwing spear. The word gasum might also share a common origin with the word geirr - "spear"

Given the distance in space and time between $1^{\text {st }}$ century Gaul and $13^{\text {th }}$ century Iceland, we will only assume a vague relationship between the objects these two words designate, just like the words "javelin" and "gavelock" (iron bar or lever, in some modern English dialects ${ }^{49}$ ), while sharing a common Germanic origin, ended up meaning quite different things, after centuries of linguistic evolution and semantic drift.

We will therefore only assume a kesja to be a shafted weapon, without any other specification.

\section{IV.1.2. Appearance in sagas}

As opposed to the other weapons studied here, the kesja appears almost exclusively in one saga, namely Egils Saga Skalla-Grímssonar. There is also a single occurrence of a kesja in Ljósvetninga Saga (in which Gudmund "plunges" it into Rindil, without other details chapter 20).

The appearances of the kesja in Egils Saga are extremely diverse, showing a large range of situations, uses, and we are even provided with a detailed description of the weapon. Egil is by far the character most often mentioned wielding a kesja, but he is not the only one.

- Four times, a kesja is mentioned as an element of the panoply of a warrior, usually consisting of a shield, a sword and a kesja (as well as a helmet and sometimes a mail shirt). In one case, the kesja belongs to Thorolf (chapter 53), in the other cases, to Egil. Sometimes Egil has the sword tied to the wrist instead of having it sheathed ${ }^{50}$.

- Egil breaks off the head of his kesja to pack it in a bundle with his other weapons (chapter 45).

\footnotetext{
48 Cleasby and Vigfusson, An Icelandic-English Dictionary.

49 Webster et al., Webster's dictionary.

50 e.g. Appendix 13.
} 
- Thorolfs kesja is described as being a brynpvari (chapter 53).

- Thorolf uses his kesja, here referred to as a spjót ("spear"), two handed, for cutting and thrusting (chapter 53).

- Thorolf's kesja pierces a mail shirt (chapter 53). The impaled opponent is lifted on it and the weapon is stuck in the ground to keep him aloft. In the same sentence, the kesja is referred to as a spjót 51 .

- Thorolf is killed when many kesjur are drawn against him / thrust at him (chapter 54).

- Egil fights with his kesja in one or two hands.

- Egil and Berg-Önund throw kesjur at each other, the weapons are deflected by the shields or get stuck in it. The weapon is here again referred to as a spjót (chapter 58).

- Egil shoots (throws or thrusts?) his kesja through shield and man.

- $\quad$ Egil uses his kesja in a naval battle (chapter 70).

The description of Thorolf's kesja, referred to as a brynpvari ("mail-stick" or "mail-spear"), is very interesting. The Old Icelandic text can be translated in the following way (based on ${ }^{52}$ and ${ }^{53}$ ):

Kesju hafoi hann $i$ hendi. Fjöđrin var tveggja álna löng ok sleginn fram broddr ferstrendr, en upp var fjödrin breid, falrinn badi langr ok digr, skaftit var eigi hara en taka mátti hendi til fals ok furouliga digrt. Járnteinn var i falnum ok skaftit allt járnvafit. Dau spjót váru kölluð brynpvarar.

He had a kesja in his hand; the blade was two ells long, and forged to a four-edged point, but at its base the blade was broad. The socket was both long and thick. The shaft was not longer that what was needed to be able to grasp the socket with the hand, and was exceedingly thick. There was an iron spike in the socket, and the shaft was all bound with iron. Such spears were called brynpvarar.

(Egils Saga, chapter 53)

\footnotetext{
51 Appendix 9.

52 Edwards and Pálsson (eds.), Egil's Saga, chap 53.

53 Zoëga, A Concise Dictionary Of Old Icelandic.
} 


\section{IV.1.3. Use as a weapon}

Table 2 summarizes the uses of the kesja in combat.

\begin{tabular}{|c|c|c|c|c|}
\hline Move & One-handed & Two-handed & Unknown & Total \\
\hline Thrusting & $1(2 ?)$ & 2 & Many & $2(3 ?)+$ many \\
\hline Cutting & 0 & 1 & 0 & 1 \\
\hline Lifting $^{54}$ & 0 & 0 & 1 & 1 \\
\hline Throwing & $2(3 ?)$ & 0 & 0 & 2 (3?) \\
\hline Fighting & 1 & 1 & 1 & 3 \\
\hline Total & 4 & 4 & $2+$ many & $10+$ many \\
\hline
\end{tabular}

Table 2: Statistics of the use of a kesja in combat in Egils and Ljosvetninga Sagas. The number of hands holding the weapon is either explicitly mentioned in the saga, or derived from the context.

We can see that the weapon is rarely used for cutting, that it can be used in one or two hands (e.g. with the shield carried on the back), and from what is described, it is used both for thrusting and throwing - which is consistent with the fact that spjot ("spear") is used several times as a synonym for the weapon.

The seldom use of cuts is, in turn, consistent with the fact that the weapon is once referred to as a böggspjót (Egils Saga, chapter 58).

\section{IV.2. Archaeological candidates}

As Table 2 shows, the kesja can be used in a variety of different ways, including throwing, thrusting, cutting... We could therefore assume the same candidates for the kesja as we did for the böggspjot and the atgeirr - which would be consistent with the hypothesis by Cleasby \& Vigfusson ${ }^{55}$ that the bögsspjott, the kesja and the atgeirr would be the same thing.

However, a heavy hewing spear does not make a very good candidate for a throwing weapon ${ }^{56}$. Besides, the description of a kesja in chapter 53 of Egils Saga can provide us with several other archaeological candidates.

A first interpretation of this description is that the kesja has a long, sturdy point, with a broad blade at its base (an axe blade?) and another spike at the socket (a back spike?) - it would then look just like an early halberd (Fig. 1).

Another interpretation is that of a spear blade with a narrow point that is flaring out quite significantly, perhaps like Fig. 3c or like the ox-tongue spear from Fig. 6c. The iron spike in the socket could then either be a crossbar, like one would have on a boar-spear (Fig. 11), or, simply, the nail or rivet which is used to attach the socket of the kesja to the shaft.

\footnotetext{
${ }^{54}$ Lifting an impaled opponent.

55 Cleasby and Vigfusson, An Icelandic-English Dictionary .

56 Although Achille Marozzo mentions the throwing of partisans (Opera Nova, Bologna, book 4, chapter $179,8^{\text {th }}$ play).
} 
Finally, the four-edged point of the kesja blade can be reminiscent of what was most likely called a brodd-spjót: "a spear ending in a four-edged point"57, 58. These brodd-spjót can have referred to slender, high-ridged spears (Fig. 8c), or to even more specific mail-piercing blades, examples of which survive from the Vendel Age, one to three centuries before the Viking Age (Fig 8a and 8b). If it was not for its size (less than $40 \mathrm{~cm}$ instead of two ells - about $98 \mathrm{~cm}$ !), the shape of the spearhead on Fig. $8 \mathrm{~b}$ could have matched perfectly the description from the saga.

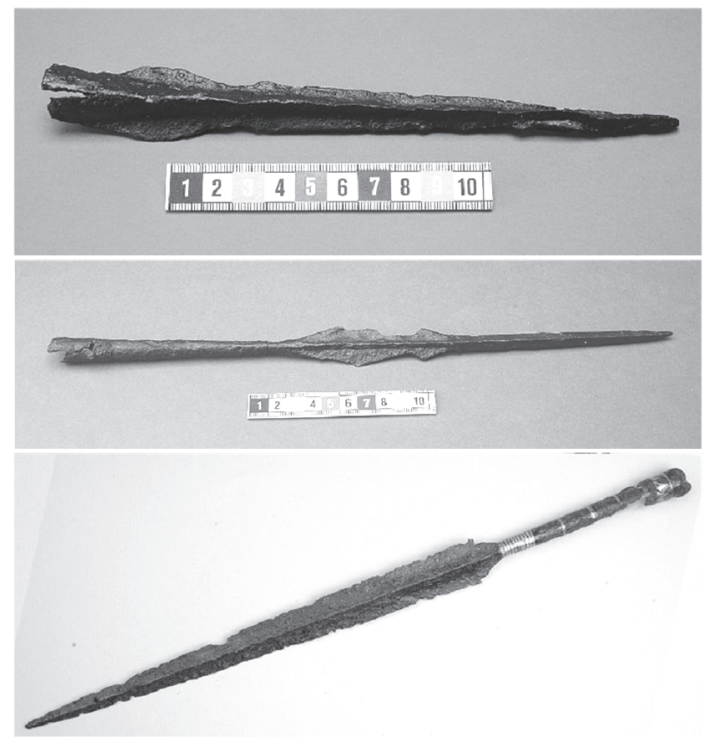

Figure 8: Scandinavian spearbeads with a four-edged point.a: strongly hollow-ground Vendel age mail-piercing spearbead, (Stockholm, Statens Historiska Museet, catalog nr. SHM 1209

(obj. 371669)), photograph: (C) Jenny Nyberg, b: high-ridged Vendel age mail-piercing spearbead widening at its base, (Stockbolm, Statens Historiska Museet, catalog nr. SHM

1209 (obj. 371670)), photograph: (C) Jenny Nyberg, c: high-ridged Viking age slender spearbead, (Stockholm, Statens Historiska Museet, catalog nr. SHM 34000:Bj 708 (obj.467387)), photograph: (O) Ulrik Skans. Reproduced with permission of the institution.

\section{IV.3. Interpretation}

The interpretation of the kesja as something very similar to a later halberd is tempting, but we have to reject it for a number of reasons.

First and foremost, halberds like those on Fig. 1 did not start emerging before the very end of the $14^{\text {th }}$ century. Therefore, such weapons would have been unknown not only to the protagonists of the saga, set in the $9^{\text {th }}$ and $10^{\text {th }}$ centuries during the reigns of Harald

\footnotetext{
57 Zoëga, A Concise Dictionary Of Old Icelandic.

58 Falk, Altnordische Waffenkunden, p. 68.
} 
Fairhair and Eirik Bloodaxe, but also to the author of the saga, writing it in the $13^{\text {th }}$ century.

For a $13^{\text {th }}$ century context, $\mathrm{H}$. Falk suggests that the brynpvari might be a variant of bryntroll (see Sect. VI.1.), and would be a kind of double-bladed axe with a four-edged point on top ${ }^{59}$, which makes it akin to a halberd. However, another reason to discard the halberd as a viable candidate is the use of the kesja as a throwing weapon in conjugation with a shield - which seems quite a ridiculous way to use a halberd.

Finally, in the description in chapter 53, the head of the kesja is referred to as a fjötr. The word fjö̈r primarily means "feather" or "quill" 60 , but can also designate a spearhead obviously due to its feather-like shape. Therefore, this word is extremely unlikely to be used to describe something like a halberd or bill blade. It is also consistent with the fact that weapons called kesja are often also referred to as spears (spjót).

We are thus left with the option of different types of spears.

An indicator of the spears to look at is the historical setting of the saga. Unlike BrennuNjáls Saga, which mostly featured $13^{\text {th }}$ century elements, Egils Saga shows an attempt of the author to be more historically accurate about the period it is describing.

It can be seen from the shields appearing in the text: not a single kite shield is explicitly mentioned, moreover, Egil's panoply is indifferently described as consisting of a kesja, sword and shield, or a kesja, sword and buckler, or a böggspjót, sword and shield. Either we assume that Egil changes weapons (but that would be inconsistent with the author writing about his "customary weapons" 11 ), or we conclude that these different words can refer indifferently to the same objects. In that case, calling the same object a shield and a buckler can show that the author has in mind a round, centre-gripped shield, which would be a larger version of a $13^{\text {th }}$ century buckler (Fig. 9). Besides, in chapter 53, the author insists on the fact that the warriors are all equipped with their "Norse shields and Norse weapons" 62 - as if to emphasize the contrast with the $13^{\text {th }}$ century weapons known to his readers. The fact that the fighters very rarely wear mail in the saga, even during pitched battles, is also an indicator of an older time period.

\footnotetext{
${ }^{59}$ Falk, Altnordische Waffenkunden, p. 111.

60 Zoëga, A Concise Dictionary Of Old Icelandic.

61 Appendix 7 and 10.

62 Appendix 8.
} 

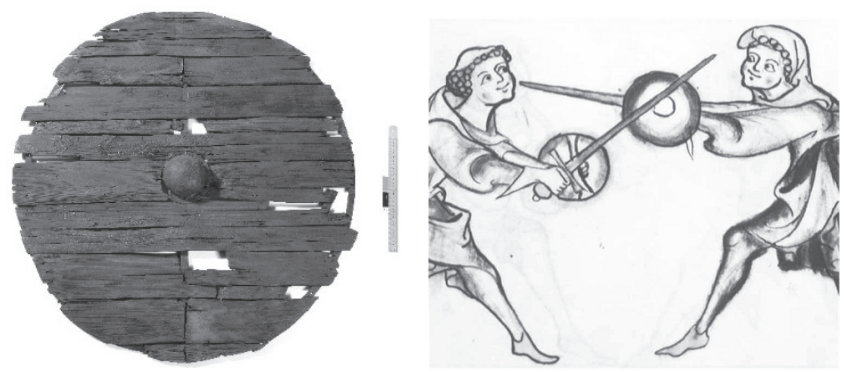

Figure 9: Example of boss-held round shields from the Viking Age to the 13th century. a: Viking shield (usual size $8090 \mathrm{~cm})^{63}$ from the Gokstad ship burial, 9th century, (Oslo, Kulturhistorisk. Museum, catalog nr. C10390b), photograph: (C) Eirik Ingens Johnsen (CC BY NC SA 4.0). Reproduced with permission of the institution. $\boldsymbol{b}$ : Bucklers used in combat, late 13th century, Liber de Arte Dimicatoria, ca. 1320 (Leed, Royal Armouries, MS I.33, f 11r), (C) Board of Trustees of the Royal Armouries.

In that scope, later designs of weapons such as an ox-tongue spear, or a boar-spear with a crossbar being the "spike in the socket" are not necessarily the best candidates for the kesja.

An attempted reconstruction of Thorolf's kesja described in chapter 53 is presented on Fig. 10. It has the four-edged point of the brodd-spjót, and a blade wide enough to act as a böggspjót - since Thorolf also uses it for cutting. The "spike in the socket" is represented as a simple nail, and the socket diameter, $4 \mathrm{~cm}$, is indeed "exceedingly thick" for a spear. Overall, it looks a lot like an oversized specimen of the spear on Fig. 8b.

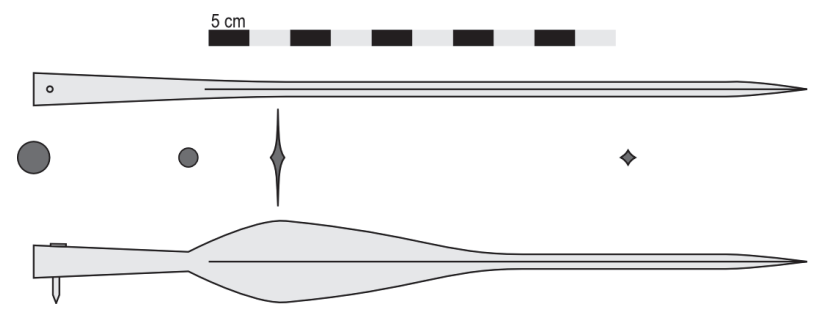

Figure 10: A bypothetical reconstruction of the kesja as described in Egils Saga: blade profiles and cross-sections.

This particular kesja gets referred to as a brynpvari. We understand that the description that was given is therefore not a description of any kesja, but of a specific type thereof. The question arises then to know what a kesja refers to in general.

The first option is that a kesja is a mail-piercing spear, a bit like the brodd-spjót. It might be, for example, that if the spear only has a four-edged (hollow-ground) point, it is a broddspjót (Fig. 8a, 8c), but if its blade it widening, then it is a kesja (Fig. 8b, 10). And if the said

63 Short, Viking shields. 
kesja is unusually big, like the one described in chapter 53 , then it is called a brynpvari. In that case, the kesja, if small enough, can be used one-handed, for thrusting or throwing, and, if big enough, it can be used to deliver two-handed cuts - which corresponds to all the descriptions of this weapon in combat. However, it would be strange to use the name "mail-spear" only for the giant version, while the smaller versions are also perfectly suitable to burst the rings of a mail shirt.

The other option is to go for a broader meaning of the word kesja, and this is suggested by the scene of Thorolf's death, killed by many kesjur. If the kesja were a special and unusual type of weapon (be it a halberd, a mail-piercing spear or anything else), it would be unlikely that many warriors among Thorolf's enemies would have this kind of weapon, unless they had a good reason for it. In the battle that Thorolf fought with his kesja (chapter 53), it is explicitly mentioned that he was not wearing mail. It is therefore most likely that he was not wearing mail either on the following day (chapter 54), when he was killed. Therefore, his opponents had no reason to use mail-piercing spears against him, and the weapons they used in great numbers to kill Thorolf were probably of common nature. We can therefore suggest that the word kesja is yet another word to designate a spear, just like spjót and geirr. The kesja, being just a spear, can then be, depending on the context, a throwing spear, a hewing spear, a mail-piercing spear...

We favour the interpretation where kesja is a rare word to designate a spear, a word that was liked by the author of Egils Saga but rarely used by others.

This hypothesis is consistent with the fact that the kesja appears numerous times in the Heimskringla by Snorri Sturluson, who is likely also be the author of Egils Saga ${ }^{64}$. This corpus should be studied as well in order to provide a better understanding.

\section{KRÓKSPJÓT}

\section{V.1. Literary occurrences}

\section{V.1.1. Etymology}

The krókaspjót $t^{5}$ or krókspjót ${ }^{60}$ is yet another weapon deriving from a spear, as the name suggests.

It is a spear (spjót) which is characterized by its krókar. A krókr is a hook, or anything crooked ${ }^{67}$. It can also be the corner of a room, and it is suggested that a krókr could be a

\footnotetext{
${ }^{64}$ Einarsson, A History of Icelandic Literature, p. 140.

65 Zoëga, A Concise Dictionary Of Old Icelandic.

66 Cleasby and Vigfusson, An Icelandic-English Dictionary.

67 Ibid.
} 
barb ${ }^{68}$, given its occurrence in the words krókspjót and krókör, which would then be a "barbed spear" and a "barbed arrow". The interpretation in e.g. favoured by Hjalmar Falk ${ }^{69}$, although he admits that barbed spears are much more common in the Iron Age (Vendel Age) than in the Viking Age and later times.

Another interpretation is that the krókar would in fact designate the "wings", or "lugs"70, which are often seen on the sockets of Migration era to Viking era Germanic spearheads, and survived in later medieval boar-spears either in the same "winged" shape, or as a crossbar (Fig. 11). This makes sense if we consider the krókspjót as a "hooking spear" and one of the primary functions of the wings on spearheads was to hook, be it to take away the shield of the opponent or to catch his spear shaft or limb. In that case, the "hooking arrow" (krókör) would be hooking flesh, and the "hooking spear" (krókspjót) would be hooking shields and spear shafts.

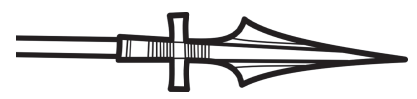

Figure 11: 13th century boar-spear. Based on the Maciejowski Bible, ca. 1245 (New York, Morgan Library, Ms. M. 638, f 27r).

The two main candidates for the krókspjót are therefore Viking Age winged spears (or 13 ${ }^{\text {th }}$ century boar-spears) and barbed spears - we will try to distinguish between the two thanks to the sagas and the archaeological artefacts.

\section{V.1.2. Appearance in texts}

The krókspjót is referred to sporadically in various sagas, not necessarily linked to one another. The name of the weapon is inconsistently translated as a "spear", a "halberd", a "barbed spear", etc.

- In Bjarnar Saga Hítdælakappa (chapter 18), Björn has a krókspjót in his hand, a shield at his side and a sword at his belt. The context of the saga is clearly from the $13^{\text {th }}$ century.

- In Egils Saga (chapter 86), an unnamed chieftain comes to the thing ${ }^{71}$ carrying richly adorned equipment, consisting of a shield with golden decorations and an ornamented krókspjót with a gilt socket.

- In Fóstbræðra Saga (chapter 2), Jöd makes a thrust with a krókspjót, which is also referred to as a spjót ${ }^{2}$. In the same saga, Snorri uses in two hands a large krókspjót (chapter 12).

${ }^{68}$ Zoëga, A Concise Dictionary Of Old Icelandic.

${ }^{69}$ Falk, Altnordische Waffenkunden, p. 69.

${ }^{70}$ Short, Viking Spear.

71 The Ping (or thing) is the ancient Scandinavian form of legislative assembly.

72 Appendix 14. 
- In Laxdœla Saga (chapter 21), Olaf has a high-status set of weapons, among which a decorated krókspjót, a shield and a sword at his belt.

- In the same saga (chapter 37), Eldgrim, wearing mail, brandishes a krókspjót in one hand, while having a shield in the other hand and a sword at his belt.

- In Grettis saga (chapter 19), Gretti picks up old Kar's large krókspjót from the wall where it was hanging, and uses it in a two-handed thrust that is able to pierce two men, with the blade buried in their bodies up to the krókar.

- In Dórðar Saga Hreðu (chapter 7), Indridi is mentioned twice having a very large krókspjót in his hand, along with a red shield and a sword.

We see that the krókspjót are usually large (or, like in the case of the höggspjót, that the described weapons are big even for a krókspjót). They are most often used in one hand, with a shield, and are primarily thrusting weapons. It also seems unusual for a large spear not to have krókar: in Grettis Saga, we learn that Gretti has a large spear, with a silver inlaid socket, but with no krókar - which seems to be worth mentioning for the author ${ }^{73}$. Such a spear might have looked exactly like Fig. 3c.

In the case of the krókspjót, we can also look at an occurrence in a Scandinavian text unrelated to the Icelandic sagas. In the Norwegian Gulathing Law, written in the $13^{\text {th }}$ century, we can find the following statement ${ }^{74}$ :

En pat er hit pridia misvigi ef madr er lostenn krocoro. aða krocspiote. oc parf at skera til.

which can translate as $^{75}$ :

The third [form of] dishonourable man-slaying is wounding a man with a barbed arrow or barbed spear, so that [the head] has to be cut out.

This text clearly draws a parallel between the vicious wounds inflicted by a krókör or krocoro ("barbed arrow") and a krocspiote. A similar situation is described with a barbed arrow in Fóstbræðra saga (Flateyjarbók), when the arrow cannot be removed without damaging the surrounding flesh, because of the barbs.

\section{V.2. Archaeological candidates}

There are archaeological artefacts to support both the winged spear and the barbed spear hypothesis.

As mentioned, the winged spears, of Petersen types B, C and $\mathrm{D}^{76}$, were very common before, during and even after the Viking Age. They came in various blade sizes and shapes,

\footnotetext{
73 Appendix 16.

${ }^{74}$ Keyser and Munch (eds.), Norges Gamle Love Indtil 1387, p. 80.

75 Larson, The Earliest Norwegian Laws, p. 160.

76 Petersen, De Norske Vikingesverd, p. 23-26.
} 
larger specimens can be seen on Fig. 3. During later Middle-Ages, it remained common for spears to have wings, lugs, hooks or crossbars, which served similar purposes as for Viking Age spears.

As for barbed spearheads, several artefacts survive as well from the Viking Age. Most of them are tanged spearheads (Petersen type $\mathrm{L}^{77}$ ), as seen on Fig. 12a. An example of a socketed barbed spearhead has also been found in Birka, Sweden (Fig. 12b), which bears a striking similarity to the earlier Germanic (Vendel Age) ango.

However, there is no evidence that these barbed spears where used as weapons of war, as it is attested for the ango. They were maybe fishing or whaling harpoons. Moreover, none of these barbed spears, be it tanged or socketed, could be described as large, decorated, gilt, etc. as mentioned in the sagas. After the Viking Age, barbed spears and javelins remained in use in Medieval Europe (probably due to the vicious wounds inflicted and to the hooking opportunities), shifting between tanged and socketed designs, and bearing one or two barbs ${ }^{78}$. It is therefore most likely that such weapons existed in the $13^{\text {th }}$ century, and were directly related to earlier and later barbed spears.

\section{V.3. Interpretation}

Given that neither the texts nor the archaeology can provide us with a unifying theory, our hypothesis is that of a semantic drift.

The studied texts date back to the $13^{\text {th }}$ century, while the studied families of weapons emerged as soon as in the $7^{\text {th }}$ century. After its colonization, Iceland remained linguistically quite isolated, while Norway got more and more links with the rest of Europe, so that the Norwegian language drifted more quickly from Old Norse than Icelandic did. In modern Norwegian, krok still means a hook (more specifically a fishing hook), but the meanings of krókspjót and krocspiote might have already diverged by the $13^{\text {th }}$ century.

77 Ibid., p. 33-34.

78 See, e.g., Die Blume des Kampfes (Vienna, Österreichische Nationalbibliothek, Cod. 10799), fo 190r. 


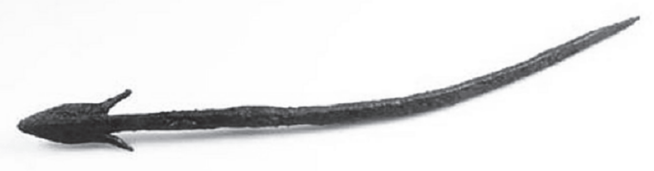

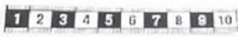

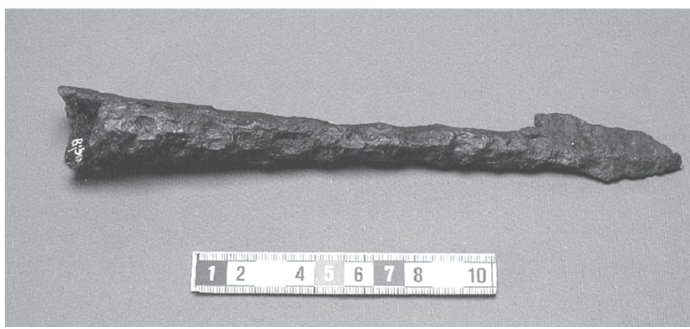

Figure 12: Examples of barbed spears from the Viking age. a: a tanged spearbead (harpoon?), Petersen type L, (Stockholm, Statens Historiska Museet, catalog nr. SHM 22293:2 (obj. 107519)), photograph: (C) Iliali Asp, b: a rare socketed spearhead (ango?), (Stockholm, Statens Historiska Museet, catalog nr. SHM 34000:Bj 596 (F101) (obj. 449486)), photograph: (C Ny Björn Gustafsson. Reproduced with permission of the institution.

On the Icelandic side, we have the description of a weapon which is quite common, often quite large, and can be a high-status weapon, worthy of a chieftain or king, and which is often gilt or otherwise ornamented. We even learn that it is uncommon for large spears (obvious weapons of war) not to have krókar - not to be a krókspjót - which is in perfect agreement with the winged spears that can be found commonly before, during and after the Viking Age. The scene where Gretti pierces two men with a krókspjót up to the krókar is also very consistent with a winged spear, since a secondary use for the wings (or primary, in the case of a later boar-spear) was to prevent over-penetration of the blade in the body of the enemy.

On the Norwegian side, we have a description which matches perfectly a barbed spear, or harpoon, through the wounds it inflicts. None of the known barbed spears are large or ornamented, and it is difficult to imagine a harpoon (or even an ango) as a high-status symbol. Besides, the ango demonstrate that the main use of a barbed spear is as a throwing weapon, while the krókspjót in the sagas are mostly used for thrusting and are sometimes used two-handed.

We therefore come to the conclusion that, while etymologically close, the krókspjót mentioned in the sagas and the krocspiote appearing in the Gulathing Law designate different objects, the former being the characteristic Viking winged spear (Fig. 3) or, in a $13^{\text {th }}$ century context, a boar-spear, and the latter a barbed spear or harpoon. 


\section{OTHER WEAPONS}

\section{VI.1. Bryntroll}

The bryntroll (or bryntröll, although this spelling might be incorrect ${ }^{79}$ ) is another weapon of unknown nature. It is suggested that it might refer to the same weapon as the brynpvar 80 , ${ }^{81}$, which is a type of kesja (see IV.3).

Etymologically, a troll is "a monstrous, evil-disposed being" 82 . The word took the metaphorical meaning of anything fiendish, so that an X-troll would be "an enemy, a destroyer of X"83. In our case, the bryntroll is the enemy, the destroyer of the brynja - the byrnie, or mail shirt. This name might therefore be a kenning, a poetical metaphor characteristic of Nordic poetry, but kennings for weapons are far less common in sagas than is skaldic poetry. It is also worth underlining that the word bryntroll was kept in use in the Icelandic language and took the meaning of a regular European halberd (Fig. 1).

We therefore have the mention of a weapon the purpose of which is to destroy (or, at least, bypass) mail.

And this is exactly what the weapon does in the sagas:

- In Egils Saga, Kveldulf raises a bryntroll and cuts (böggva) at Hallvard (chapter 27). The cut goes through the helmet and into the head, burying the blade up to the shaft. The blade gets stuck in the skull, so that when tugging it back, Kveldulf swings Hallvard's body to the other side.

- In Harðar Saga Og Hólmverja (chapter 28), Hörd is wounded by a bryntroll.

- In Laxdœla Saga (chapter 37), Hrut owns a gold inlaid bryntroll, which is a royal gift. He uses it to kill Eldgrim from behind, by raising and "driving" (setja) the bryntroll between his shoulders, splitting the mail shirt. The bryntroll then "runs through the chest".

- In Valla-Ljóts Saga (chapter 2), Ljot owns an inlaid bryntroll. He carries it when he is in a good mood, as opposed to the sharp-horned axe he carries when in a killing mood. Ljot uses the bryntroll to keep attackers at bay during an ambush, and to deflect a spear thrown at him (chapter 8).

We can see that as opposed to the previously studied weapons, the bryntroll mostly cuts, and impressively so. Besides, it seems to be used two-handed, since no shield is mentioned

\footnotetext{
${ }^{79}$ Cleasby and Vigfusson, An Icelandic-English Dictionary.

80 Zoëga, A Concise Dictionary Of Old Icelandic.

${ }^{81}$ Falk, Altnordische Waffenkunden, p. 111.

82 Zoëga, A Concise Dictionary Of Old Icelandic.

83 Cleasby and Vigfusson, An Icelandic-English Dictionary.
} 
in any of its appearances. And, given that the weapon is buried "up to the shaft" when delivering a cut, the blade must be mounted so that the shaft is behind the blade. We might therefore finally have something closer to a long-shafted axe - even more so that in Egils Saga and Laxdœla Saga, other weapons like the böggspjot, the atgeirr, the kesja and the krókspjót are mentioned, but never compared to the bryntroll.

However, the bryntroll is supposed to be contrasting with Ljóts sharp-horned axe. If we suppose this axe to look like a Danish axe or a later large battle axe (Fig. 13), then the bryntroll must have had quite a different look. We must think then of another pole-weapon that is not a spear.
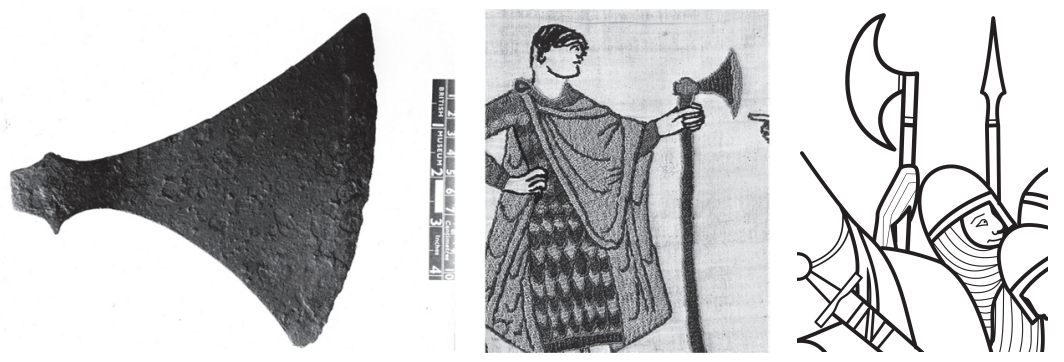

Figure 13: Axes from the Viking Age to the 13th century.

a: large Viking axe-head ("Dane axe"), 10 th-11 th century, (London, British museum, catalog nr. 1891,0905.8), (C) British Museum (CC BY NC SA 4.0).

b: Norman two-handed axe, direct descendent from the previous one. Bayeux Tapestry, late 11th century, with special authorization of the city of Bayeux.

c: $1^{\text {th }}$ century long-shafted battle axe - the shape is more crescent-like, the size of the blade and length of the shaft have increased. Based on the Maciejowski Bible, ca. 1245 (New York, Morgan Library, Ms. M. 638, $f^{\circ} 35 r$ ). Similar one-handed axes are shown as well

(Fig. 5b).

Apart from various spears and axes, there is no evidence of other pole-weapons in the Viking Age, therefore, if the bryntroll is neither spear nor axe, it is either an unknown weapon (so rare that no archaeological artefact had survived to modern days), or it has to be an anachronistic weapon, known to the $13^{\text {th }}$ century authors, but posterior to the Viking Age. The hypothesis of a rare (or foreign, or later) weapon is favored by Hjalmar Falk $^{84}$, who sees the bryntroll as a double-bladed axe or a twybill.

Given the feats the bryntroll achieves, a possible candidate among $13^{\text {th }}$ century weapons could also be a huge-bladed glaive or falchion (Fig. 5a, 5b). This weapon is shown in one instance cutting in half a mail-clad knight, which is probably an exaggeration of the artist, but is by far the most impressive cut depicted in the whole Maciejowski Bible manuscript ${ }^{85}$.

\footnotetext{
${ }^{84}$ Falk, Altnordische Waffenkunden, p. 111.

85 Anonymous, Maciejowski Bible, Ms. M. 638, ca. 1245, fo 10v.
} 
However, in this case we are just guessing what a bryntroll might have looked like, and we can give no assertive conclusion on this weapon.

\section{VI.2. Fleinn}

The last weapon we will study here is the fleinn. This word seems to designate a poleweapon with a cutting and thrusting capacity.

The meaning of the word is unclear, because of its rarity. The Old Icelandic fleinn has an equivalent in Ancient Swedish with flán. The possible meanings of the word include "a bayonet-like pike", "the fluke of an anchor" or "a kind of shaft, a dart" (mostly for the Swedish counterpart) ${ }^{86}$.

If we venture out of the martial context, the interpretation as a "shaft" might be reinforced by the word flann-fluga ("a woman who runs away from her wedded husband") ${ }^{87}$. The male counterpart of flann-fluga is fud-flogi ("a runaway from his betrothed bride"), which derives from the word fuð_ "cunnus" 88 . Therefore, if the fud-flogi is "fleeing the cunt", it makes sense to see the flann-fluga as being "fleeing the shaft".

If we leave aside the "bayonet-like pike" because it might narrow down our interpretation, we are left with a word designating something similar to a shaft (or fluke, or dart). This is coherent with the interpretation of Hjalmar Falk ${ }^{89}$, who sees the fleinn indifferently as a throwing spear or an arrow.

The fleinn appears only three times in the Icelandic Sagas. This rarity makes it even more difficult to obtain a statistical analysis of the contexts in which this weapon is mentioned.

In Brennu-Njáls Saga (chapter 30), Kolskegg throws a fleinn at Karli’s ship ${ }^{90}$ but it seems to refer here to the fluke of an anchor, or grapnel. In Grettis Saga (chapter 66), Gretti fights a giant who is said to be wielding a fleinn, described as a heftisax, a weapon with which he can cut and thrust. Finally, in Heiðarvíga Saga (chapter 33), in a situation where peace must be kept, the author uses the expression "no fleinn shall be reddened", referring broadly to all weapons.

\footnotetext{
86 Cleasby and Vigfusson, An Icelandic-English Dictionary.

87 Ibid.

88 Ibid.

${ }^{89}$ Falk, Altnordische Waffenkunden, p. 66.

90 Appendix 1.
} 
Assuming that a fleinn is always the same thing as a heftisax (literally, a "hafted sax") is probably a mistake, and the reason why the word was said to have the meaning of a "bayonet-like pike" 91 . The interpretation of the heftisax as a bayonet-like pike makes sense - one can imagine a sax being affixed to the end of a pole, providing a primitive glaive. This construction would even be reminiscent of the much later svärdstav, used by Swedish militias around the year $1500^{92}$ - although assuming a lineage between the two weapons would be far-fetched.

In the sentence "no fleinn shall be reddened", the word also seems to be used as a generic name for weapons. It is unlikely that a word usually designating a very specific poleweapon would be used in this context. We might think that fleinn is then a rare synonym for vapn ("weapon"), but this takes us a bit too far, because we are losing the "shaft, fluke, dart" meaning of the word. A middle way is to point out the fact that the most common weapon on most of the battlefields from the Viking Age to the $13^{\text {th }}$ century was by far the spear (light or heavy, winged or not...). Saying "no spears shall be reddened" would probably sound to a $13^{\text {th }}$ century reader just as "no guns shall be fired" would sound to us - we don't need to know that throwing grenades and stabbing with bayonets is forbidden as well to understand the meaning of peace implied by the sentence.

In this scope, it seems reasonable to conclude that the word fleinn is simply yet another (rare) word to refer to a spear, or to a shafted weapon in general maybe including even light javelins and arrows.

\section{CONCLUSION}

As we have shown, the rarer pole-weapons of the Icelandic Sagas should not be called "halberds" without a reason. Based on the correlations between the text, the artefacts and their uses in combat, we can propose a range of new interpretations for the weapons studied in the article:

- the böggspjót is simply a "hewing spear", and it corresponds to any large spear with a good cutting capacity. Such a spear would be used mostly for thrusting, but occasional slicing or chopping motion can be effective too, which makes it similar in its wielding to a later partisan.

- for the atgeirr, the translations "battle-spear" or "overspear" (to emphasize the uniqueness of the weapon) should be preferred to the word "halberd". Although it is not fully clear what archaeologically the atgeirr was, its geometry and use (prevalent thrusts and occasional cuts) show that it was probably a specimen (or subtype) of hewing spear.

${ }^{91}$ Cleasby and Vigfusson, An Icelandic-English Dictionary.

92 Dolstein, Landskecbt's diary, ca. 1502. 
- the kesja appears in such a variety of situations that is probably refers to a broad category of objects as well, including throwing spears - hewing spears and mailpiercing spears - such as the brympvari. It is most probably another word for "spear", but a rare one, of ancient origin. Translators might try to use obsolete English synonyms for "spear" to translate this word, like e.g. "gar".

- the krókspjót, in the context of the sagas, is most likely a "winged spear", rather than a "barbed spear" it refers to large-bladed, often ornate weapons, and the wings (krókar) can be used for hooking motions, as well as for avoiding a too deep penetration of the spear into the opponent's body.

- the bryntroll is the least understood weapon of all. It is predominantly a cutting pole-weapon, while being quite distinct from an axe. Any reader would understand that a "mail-troll" in fearsome weapon able to split a mail shirt, but further research on closely related names (brynfagd, brynpvari) in other texts would be needed to better grasp the nature of this pole-arm, which is in any case a post-Viking-age weapon.

- the fleinn seems to refer to the general concept of a shafted weapon, be it a spear, a javelin or an arrow. Depending on the context, it would be probably best rendered as simply a "spear", or a "pole-wepon", etc.

Further and better understanding of these weapons could be provided by an expanded literary study. An even larger corpus of Old Icelandic (Old Norse) texts dating from the Viking Age to the $13^{\text {th }}$ century - skaldic poetry, and sagas such as the King's Mirror (Heimskringla), the Sagas of Kings, the Legendary Sagas - could be analysed, and compared to texts in other languages about the same period (such as the Gesta Danorum by Saxo Grammaticus, Frankish and Anglo-Saxon chronicles, Arabic travel impressions, etc.). We would also benefit from a more systematic study of archaeological artefacts from the Viking Age to the $13^{\text {th }}$ century, which could provide a more complete classification of pole-weapons. However, this would be enough work for a thesis - in contrast, this short article was made possible only thanks to the fantastic preliminary work done by William R. Short ${ }^{93}$.

\section{Acknowledgements}

First and foremost, I want to thank my comrades and mentors, Thomas Mainguy and Romain Wenz, for the fruitful conversations we had, the ideas and insight they provided, and their spontaneous offer to proof-read this paper.

I want to thank heartily Mr. Gilles Martinez for providing me with illustrations and invaluable information about spear fighting.

93 Short, Arms and Armor in Sagas. 
I would also like to thank Mrs. Katarina Nimmervoll and Mr. Gunnar Andersson from the Stockholm Historiska Museet for helping me with the archaeological part of my research.

\section{BIBLIOGRAPHY}

\section{Primary sources}

Anonymous, Bandmanna saga, Bárðar saga Snafellsáss, Bjanar saga Hitdalakappa, Brennu-Njáls saga, Droplaugarsona saga, Egils saga Skallagrimssonar, Eiríks saga rauda, Eyrbyggja saga, Finnboga saga ramma, Fljótsdala saga, Flóamanna saga, Fóstbradra saga, Gísla saga Súrssonar, Grettis saga, Granlendiga saga, Granlendiga páttur, Gull-Dóris saga, Gunnars saga Keldugnúpsfifls, Gunnlangs saga ormstungu, Hallfredar saga, Hardar saga ok Hólmverja, Hávardar saga Ísfiroing, Heiðarvíga saga, Hrafnkels saga Freysgodi, Hansna-Dóris saga, Kjalnesinga saga, Jökuls páttur Búasona, Kormáks saga, Króka-Refs saga, Laxdala saga, Ljósvetninga saga, Reykdala saga ok Viga-Skútu, Svarfdala saga, Valla-Ljóts saga, Vatnsdala saga, Viga-Glüms saga, Viglundar saga, Vopnfiröinga saga, Dórdar saga breðu, Dorsteins saga hvita, Dorsteins saga Sidu-Hallssonar, Ölkofra saga, $13^{\text {th }}$ century, ed. by Bragi Halldórsson et al. (Reyjavík: Mál og menning, 1998).

Anonymous, Gulapingslög, 13 $3^{\text {th }}$ century, ed. by R. Keyser and P. A. Munch (Norges Gamle Love Indtil 1387, Christiania: Chr. Gröndahl, 1846), translated by L. M. Larson (The Earliest Norwegian Laws, Oxford: Oxford University Press, 1935).

Achille Marozzo, Opera Nova, Bologna, 1536.

Paul Dolstein, Landskecht's diary, 1502 (Weimar: ThHtStAW Ernestinisches Gesamtarchiv, Reg. S fol. 460).

\section{Pictorial sources}

Anonymous, Bayeux tapestry: La telle du conquest, ca. 1077 (Bayeux, $0.5 \mathrm{~m}$ x $68.38 \mathrm{~m}$ embroidered cloth).

Anonymous, Maciejowski Bible, ca. 1245 (New York: Pierpont Morgan Library, Ms M. 638).

\section{Secondary sources}

Cleasby, Richard and Vigfusson, Gudbrand, An Icelandic-English Dictionary (Oxford: At the Clarendon Press, 1874).

Einarsson, Stefán, A History of Icelandic Literature (Baltimore: Johns Hopkins Press, 1957).

Falk, Hjalmar, Altnordische Waffenkunde (Kristiania: Dybwad i Komm., 1914).

Gylfason, Dorsteinn, Njál's Saga, Introduction (Ware: Wordsworth Classics, 1998).

Hreinsson, Viðar, editor, Attwood, Katrina C., translator, The Complete Sagas of Icelanders

(Reykjavík: Leifur Eiriksson Publishing, 1997). 
Keller, May L., The Anglo-Saxon Weapon Names Treated Etymologically and Archaologically (Heidelberg: Carl Winter's Universitätsbuchhandlung, 1906).

Mallet, Paul Henri, Scott, Walter et al., Northern Antiquities: Or, An Historical Account of the Manners, Customs, Religion and Laws, Maritime Expeditions and Discoveries, Language and Literature of the Ancient Scandinavians (London: H. G. Bohn, 1847).

Nicolle, David, Knight of Outremer, 1187-1344 (Oxford: Osprey Publishing, 1996).

Oakeshott, Ewart, European Weapons and Armour: From the Renaissance to the Industrial Revolution (Oxford: Boydell Press, 2012).

Petersen, Jan G.T. De Norske Vikingesverd, (Kristiania: Dybwad i Komm., 1919).

Short, William R., Viking Age Arms and Armor: Viking Shields, $<$ http://www.hurstwic.com/history/articles/manufacturing/text/viking_shields.ht m>, accessed 3 March 2016.

Short, William R., Viking Age Arms and Armor: Viking Spear, $<$ http://www.hurstwic.com/history/articles/manufacturing/text/viking_spear.htm $>$, accessed 3 March 2015.

Short, William R., A Listing of References to Arms and Armor in the Sagas of Icelanders, $<$ http://www.hurstwic.com/library/arms_in_sagas $>$, and references therein, accessed 3 March 2015.

Sigurðsson, Gísli, The Medieval Icelandic Saga and Oral Tradition: A Discourse on Method (Cambridge: Harvard University Press, 2004).

Sveinsson, Einar Ól, Laxdoela saga, preface (Reykjavík: Hið íslenzka fornritafélag, 1934).

Webster, Noah et al., Webster's international dictionary of the English language (Springfield: G. \& C. Merriam Co, 1913).

Zoëga, Geir T., A Concise Dictionary Of Old Icelandic (Oxford: At the Clarendon Press, 1910). 


\section{APPENDIX}

Citations from the Sagas of Icelanders showing particularly interesting appearances of the studied pole-weapons. The (modern) Icelandic text is given along with a proposed translation.

1. Brennu-Njáls Saga, chapter 30:

Kolskeggur preif upp akekeri og kastar á skip Karls og kom fleinninn i bordid og gekek út i gegnum og féll par inn sar kolblár.

Kolskegg snatched up a grapnel and cast it at Karli's ship, and the fluke fell inside the hold, and went out through one of the planks, and in rushed the coal-blue sea.

2. Brennu-Njáls Saga, chapter 30:

Hallgrimur hefir atgeir pann er hann hefir látid seida til að honum skal ekeki vopn ad bana verda nema hann. Dad fylgir og að pegar veit er víg er vegið med atgeirinum pvi ad svo syngur í honum ádur ad langt beyrir til.

Hallgrim had an atgeirr on which he had put a spell, to the effect that no other weapon that this could kill him. Another thing is that it is known at once when a man is to be slain with the atgeirr, for something sings in it so loudly that it may be heard a long way off.

3. Brennu-Njáls Saga, chapter 45:

Sigmundur hafdi bjálm á höfoi sér og skejöld á hlið og gyrdur sverdi og hafoi spjót i hendi.

Sigmund had a helmet on his head and a shield at his side and was girded with a sword and had a spear in hand.

4. Brennu-Njáls Saga, chapter 54:

Gunnar malti til peirra: "Nú er à̃ verja sig. Er hér nú atgeirinn."

Gunnar said to them: "It is time to defend yourselves. Here is the atgeirr."

5. Brennu-Njáls Saga, chapter 63:

Litlu sỉdar skýtur Gunnar til Barkar atgeirinum og kom á hann midjan og i gegnum hann og niður i völlinn.

Shortly after, Gunnar shot the atgeirr at Bork, it went through him at the waist and then into the ground.

6. Brennu-Njáls Saga, chapter 63:

Gunnar sér petta og varpar sér skjótt til höggs vid Austmanninn og snídur hann i sundur i midju.

Gunnar saw this and threw himself at the Easterner with a hacking blow and cut him in two at the waist.

7. Egils Saga, chapter 43:

Egill hafdi vopn sin, sverd og kesju og buklara.

Egil had his weapons, a sword, a kesja and a buckler.

8. Egils Saga, chapter 53: 
Allt lið peirra hafdi norrana skjöldu og allan norranan herbúnað.

All of them had their Norse shield and all Norse weapons.

9. Egils Saga, chapter 53:

Siðan lagði bann spjótinu fyrir brjóst jarlinum, i gegnum brynjuna og búkinn, svo að út geke. um berðarnar, og hóf hann upp á kesjunni yfir höfud sér og skaut niður spjótshalanum i jördina, en jarlinn safoist á spjótinu, og sáu pad allir, baði hans menn og svo hans óvinir.

Then he thrust the spear at the earl's chest, through the mail-shirt and the body, so that it came out between the shoulder blades. He lifted him on the kesja over his head, and stuck the spear-butt into the ground. Everyone saw that the earl died on the spear, both his men and his enemies.

10. Egils Saga, chapter 58:

Egill hafdi vopn sin, pau er hann var vanur að hafa, hjálm og skjöld, gyrdur sverdi, höggspjót i hend.

Egil had his customary weapons, a helmet and shield, a sword at his girdle, a böggspjót in his hand.

11. Egils Saga, chapter 58:

Egils spjót koom á midjan sk.jöldinn og gekek i gegnum langt upp á fjöðrina.

Egil's spear hit the middle of the shield and the whole length of the spear blade penetrated it.

12. Egils Saga, chapter 58:

Egill snerist i móti peim; hann skaut kesjunni að Fróda og ígegnum skejöld hans og i brjóstið, svo að yddi um bakij.

Egil turned to face them; he shot his kesja at Frodi, through his shield and his chest, so that the point came out through his back.

13. Egils Saga, chapter 66:

Gekek Egill fram og hafơi hjálm á höfoi og skejöld fyrir sér og kesju i hendi, en sverdið Dragvandil festi hann vid hagri bönd sér.

Egil came forward with a helmet on the head, a shield in front of him and a kesja in hand, and he had his sword Slicer tied to his right hand.

14. Fóstbræðra Saga, chapter 2:

Jöjur hafdi krókaspjót i hendi. Hann snarar pá ad Hávari og leggur spjóti i gegnum hann.

Jöd had a krókspjót in hand. He turned suddently to Havar and thrust the spear through him.

15. Gísla Saga, chapter 2:

Gisli hjó i móti með höggspjóti og af spordinn skildinum og af honum fótinn.

Gisli struck back at him with his höggspjott, both through the tail of the shield, and through his leg.

16. Grettis Saga, chapter 48: 
Hann hafoi hjálm á höfdi og gyrdur saxinu og spjöt mikid i hendi og öngvir krókarnir á og var silfurrekinn falurinn á.

He had a helmet and was girded with a sax, and he had a large spear in his hand, with no barbs but with a silver-inlaid socket.

17. Kormáks Saga, chapter 16:

Bersi hafoi höggspjót $i$ hendi og staf $i$ annarri en Halldór Hviting.

Bersi had a böggspjót in one hand and a staff in the other, and Halldor had [the sword] Hviting.

18. Króka-Refs Saga, chapter 3:

Hann tekur ofan höggspjót mikið. [...] Refur gengur nú úr gardi og fer á pá leið að hann skýtur spjótinu fyrir sig og hleypur par eftir

He took down a large höggspjót. [...] Ref went out of the farm and went along the road, throwing the spear ahead of himself and running after it.

19. Ljósvetninga Saga, chapter 12:

[...] pú og sagðir hann eigi vera mundu meira en annarrar handar mann gilds manns og kvaðst hann hafa bálfpynnu eina i hendi en mig höggspjót gilt á hávu skafti. En eg em nú minni höfoingi en pú og sýnist mér sem hann muni eigi par lengi gengið hafa skaftamuninn.

[...] and you said that he was only half a real man and had only a small axe while I had a long-shafted böggspjót. I am lesser a chieftain than you, but I think that it didn't take him long to make up the difference between an axe and a pole-weapon.

20. Vopnfirðinga Saga, chapter 2:

Svartur hljóp að honum og leggur til hans með höggspjóti miklu.

Svart ran at him, and thrust at him with a large böggspjót. 